\title{
Measuring Logistics Performance: the Effectiveness of MMOG/LE as Perceived by Suppliers in the Automotive Industry
}

\author{
Alexandre Reis Graeml \\ UP/UTFPR \\ agraeml@up.edu.br \\ Jurandir Peinado \\ UP \\ jurandir@up.edu.br
}

\begin{abstract}
In spite of logistics having grown in importance lately, which included the discussion of concepts such as integrated logistics and supply chain management in the business agenda, little has been discussed about how to measure logistics performance. This paper analyzes the perception of logistics professionals about the effectiveness of MMOG/LE (Materials Management Operating Guideline/Logistics Evaluation), which is a set of recommendations regarding logistics and materials management that was created by the automotive industry to be used by those comprising its supply chain. The respondents, who were naturally all from the automotive industry (they were suppliers of large vehicle assemblers with industrial plants located in Brazil), had been previously trained on this logistics performance evaluation tool in order to implement it in their organizations. They filled in an email survey with Likert scale questions, early in 2008. Among other findings of the research, it was noticed that the impact of the MMOG/LE recommendation is stronger with respect to activities that had not been previously addressed by quality norms and recommendations. Most respondents also considered that their organizations were already efficient in integrating their activities with their customers (car assemblers) but rarely with their suppliers, which was acknowledged to be the bottleneck of their logistics systems.
\end{abstract}

Key-words: logistics, performance evaluation, MMOG/LE, Q1, EAQL, VBA

\section{INTRODUCTION}

As early as the late 1950's there were already studies that recommended the benefits of coordinated logistics. Hirschman (1958) considered that strong linkages between suppliers and buyers could support a nation's economic development as well as that of organizations, themselves. New types of relationships among buyers and suppliers companies have been implemented, leading to different kinds of physical arrangements in industrial chains, with an impact on the way they manage the operations and their economic and productive performance (ALVES FILHO et al, 2002). However, for many reasons, the possibility of better coordinating the activities of different players along the value chain only really caught the attention of practitioners and academia much more recently.

One such reason for increasing the focus on logistics processes was that companies realized that they could not improve competitiveness by just reducing their internal costs, any longer. Part of the effort to enhance efficiency involves coordinating activities with customers and suppliers (HARRINGTON, 2005). Having solved many of their internal inefficiencies, organizations are now concerned with improving their external links to business partners.

La Valle (2007) has been benchmarking physical distribution services since 1994, carrying out ca. 600 in- 
terviews with executives in different parts of Brazil, involving four product categories: perishable food, non-perishable food, hygiene and cleaning products. His methodology takes into account eight dimensions: product availability, order cycle time, consistency of delivery schedule, delivery frequency, delivery system flexibility, efficiency in solving system problems, support information systems and support to physical delivery. After analyzing the data he gathered, La Valle (2007, p. 11) acknowledged "the existence of strong potential for differentiation based on the quality of the physical distribution service". The results of his survey showed that those companies that have a better logistics performance are perceived by retailers as being superior and are given priority in future commercial relationships.

When evaluating the level of sophistication of Brazilian logistics suppliers for the industrial sector, Wanke, Fleury and Hijjar (2007), on the other hand, developed a logistics sophistication index, based on variables that assess organizational structure, information technology and performance measurement. By means of such index, they claim that they can significantly segment the industrial sector with respect to their willingness to improve their logistics performance, outsource their logistics activities, focus on value added services and with respect to the criteria organizations use to choose their logistics partners.

Ferreira and Alves (2005) examined the impacts on logistics of the electronic exchange of information among companies using EDI (Electronic Data Interchange) or Internet tools. They highlight the emphasis that is given to the use of such technologies in the automotive industry, where suppliers are pressed by automakers to make intensive use of logistics coordination information technologies. These authors conclude that the agility in electronically exchanging logistics information contributes to the competitiveness of the supply chain, enabling the consolidation of cargo (cost) and the possibility of postponing logistics tasks (responsiveness). In a study about changes in relationships and strategies for better coordination of the supply chain, Silva and Alcântara (2001) also concluded that the adoption of logistics systems and information technologies, such as EDI, represent an incentive for organizational change based on new forms of supply chain management. They help organizations to find more cooperative ways to run their businesses, leveraging strategic alliances.

Neumann, Rieder and Müller (2007) remind us that supplier evaluation is no longer just a cost issue. Over the last thirty years, more and more companies have started considering quality and delivery also as important evaluation criteria in a purchase decision. Now-a-days, choosing suppliers involves, according to those authors, three major issues: price, quality and delivery. As productivity and quality have long been addressed by many organizations, they do not offer much opportunity for differentiation, anylonger. In a case study regarding logistics practices in an automotive industry supply chain, Rodrigues and Sellitto (2008) conclude that the potential of collaboration techniques has not been exhausted: there are still important opportunities for improvements. According to the authors, the quality area of the organizations should interact more with suppliers, since the development phases of products, by means of ESI (Early Supplier Involvement) tools like APQP (Advanced Product Quality Planning), making the rolling out of new products more agile and efficient.

Abrahamsson, Aldin and Stahre (2003) were able to show that logistics can be used to achieve a competitive edge, having noticed that the most successful companies with respect to growth and profitability are well integrated to their supply chains. Based on that, they describe, define and exemplify the need for very flexible logistics management, as a key factor to improve profitability and growth.

The rush for differentiation based on better logistics performance in recent years has increased the level of details and the complexity involved in any logistics process. This calls for new shareable metrics to be developed in order to assess the actual effectiveness of a company's effort to ensure delivery of its products to customers at the right time, quantity and quality.

In spite of logistics having been brought to the center of attention of many organizations, in recent years, evaluation tools to assess the effectiveness of the logistics performance and academic research about the issue are still scarce.

The research that is reported in this paper had the purpose of understanding what users think of a specific logistics performance evaluation tool, called MMOG/LE. The authors wanted to know the respondents' impressions on the effectiveness of such tool with respect to the following issues: strategy, work organization, capacity and production planning, improvement of the interface with customers, product and production control and improvement of the interface with suppliers. 
From a practical point of view, the results of the research could help spreading information on the potential benefits of MMOG/LE), in case it were considered effective, to other industrial sectors (it was originally developed for and by the automotive industry). It is a readily available model (freely accessible through the Internet from the web-sites of its proposing agencies) and has a very low implantation cost, considering that the evaluation form is an MS Excel sheet. Even if the results of this research project were not favorable to MMOG/LE, that could also represent an important conclusion, meaning that it would have to be improved, in order to become useful, or replaced by another tool that could do what it claims in a more effective way.

From a theoretical angle, performing the research was also justifiable, because, in spite of all the fuzz about logistics and supply chain management, very few academic studies have dealt with the evaluation of logistics performance, which has become a very relevant issue. One cannot manage something that one cannot measure1, after all.

It should be highlighted that this study was not interested in evaluating the quality of the logistics management that is performed by the companies involved in the survey. It only intended to identify the respondents' perceptions about the suitability and effectiveness of the use of MMOG/LE as a tool to evaluate and improve logistics performance.

After this brief introduction, we will discuss in further detail the need to assess performance in logistics activities. After that, we will present the MMOG/LE tool. Then, we will describe the methodology used to collect and analyze the data, followed by the presentation and discussion of the results. At last, the paper brings the authors' final considerations, which include suggestions for future research projects.

\section{Measuring the Performance of Logistics Processes}

Changes in the way they organize their operations and manage their supply chains in order to become more agile and flexible are not exclusive to Brazilian organizations. All over the world, companies have been struggling to become more competitive in the global market and one way of achieving that is by improving the coordination of their supply chains in order to succeed in delivering more efficiently (SCAVARDA AND HAMACHER, 2001)

As a result of the increase in the awareness about the importance of logistics processes, ways of measur- ing and assessing logistics performance started being discussed in many organizations. Hijjar, Gervásio and Figueiredo (2005) analyze the World Class Logistics model, highlighting the fact that a good performance monitoring system is essential to managing logistics activities. Those authors consider that performance measurement is essential to check if the targets that were set by (and for) an organization are being achieved, helping in the decision making process about where to spend scarce resources. Monitoring logistics processes "is even more important in the current scenario, in which logistics related activities have been globally acknowledged as being fundamental for the generation of value to the customer" (HIJJAR, GERVÁSIO and FIGUEIREDO, 2005 , p. 1). In a review of interorganizational information management (IOIM) in an automotive supply chain, Costa and Maçada (2009) observed that the exchange of information among four investigated companies was about the price, product, quantity, specifications, delivery date, order number and classification, so it was basically operational. The authors also noticed that each company had a different way of managing information, which could not be defined as a model of IOIM.

A recent paper by Teixeira and Lacerda (2010) aims to provide an analysis of the major topics discussed in 173 papers published about supply chain management in the most important international production and operations management journals between 2004 and 2006. The results show that the major topics are coordination, information sharing among companies, production decisions, and supply chain design and performance.

Tontini and Zanchett (2010) claim that the quality of logistics services involves five main dimensions: reliability, responsiveness, flexibility, safety and empathy. The logistics services, themselves, concern these dimensions, which can be translated as: reliability of delivery with respect to time and quantity; delivery agility and response to customer requests; safety in conducting business with the company; flexibility in the provision of services; and ability and interest to address special needs.

New logistics evaluation tools have been also created and applied for third party logistics providers (3PL). Yan, Chaudhry and Chaudhry (2003) developed a methodology for the evaluation of logistics performance specifically oriented to the measurement of the quality of the service provided by those suppliers, which is perfectly justifiable as a result of 
the increasing demand for this type of service. The methodology uses the CBR (case-based reasoning) in a type of decision model to solve problems related to the selection of logistics service providers by the hiring party. The method is based on adaptations of lessons that were learned from previous similar experiences, inspired on the way human beings decide, learning from their own mistakes. The measuring system used to select a logistics operator is based, according to these authors, on four relevant factors: 1. information on the business environment; 2 . information on services that were carried out by the assessed company in the past; 3 . technical and financial information and managerial terms; and 4. the importance of each type of information. According to Yan, Chaudhry and Chaudhry's (2003) research, the method proved efficient in the field.

Martins and Gonçalves (2004) study the effectiveness of a performance indicators' system comprising technical and commercial features, developed in order to provide better understanding of the relationship between car assemblers and their supply chains. They anticipated a discussion that became main stream a few years latter, leading several European and North-American car assemblers to unify their logistics performance evaluation standards and requisites, having as a starting point the initiatives of the assemblers' associations in both continents (Odette and AIAG, respectively), which jointly developed the MMOG/LE recommendation, as described below.

\section{THE MMOG/LE RECOMMENDATION}

MMOG/LE - Materials Management Operating Guideline/Logistics Evaluation - is a set of recommendations regarding logistics and materials management, which was created by the automotive industry to be used by those comprising its supply chain (HARRINGTON, 2005), but which can easily be adjusted to other industries.

The MMOG/LE recommendations consist on an Excel file containing questions about the company's practices and procedures for its logistics management. According to the recommendation itself, it provides three important outputs (AIAG and ODETTE, 2006):

- Internal assessments: MMOG/LE provides guidance for internal audits of the logistics management practices;
- Performance measurement: the internal assessment based on the MMOG/LE recommendation allows a grade to be assigned to the logistics performance of the organization. The standardization of evaluation procedures makes it easier to benchmark results, then; and

- Improvement plans: internal assessment helps identifying issues that need to be addressed, called gaps. Therefore, it can be used to guide the implantation of continuous improvement plans, internally to the organization, or in conjunction with suppliers.

Companies that supply parts or components to several different assemblers at the same time were faced with great difficulty to prove the quality of their logistics processes to all different customers, as each of them had their own logistics evaluation demands. In spite of sharing the same purpose, i.e. being sure that the suppliers would feed them with the right supplies at the right time, they had different guidelines on how to achieve that2. That was the main reason for AIAG and Odette, the two organizations that congregate the automotive industry in North America and Europe, to work together in the development of a logistics evaluation tool that could be used by everyone (AIAG, 2006). The importance of standardizing logistics evaluation processes along the whole industry is highlighted by Witt (2005, p. 20), who states that "all global supply chains have essentially the same activities: receiving, storing, shipping and transporting". The problem is that "these supply chains have spoken in different languages".

Thus, the MMOG/LE recommendation was created to meet two important specific demands of the automotive industry: (1) the need to define common criteria for the evaluation of logistics performance, and (2) the need to unify all sort of recommendations and norms, demanded from the suppliers by large automakers (HARRINGTON, 2005; INTERNET AUTOGUIDE, 2004). The main purpose is, therefore, to provide means for a standardized evaluation of logistics and materials planning, that can be used by suppliers and customers (the assemblers) alike, in the automotive industry. MMOG/LE was conceived to be used by any party in the supply-chain, as a self-assessment tool, but also as a tool for business partners to assess the quality of services provided by other parties.

Witt (2005) highlights the fact that the logistics evaluation provided by MMOG/LE translates the jargon 
of logistics managers and shows its processes in a way that anybody can understand their meaning.

\section{METHODOLOGICAL PROCEDURE}

This study was carried out based on data that was collected by means of a structured survey, containing 20 Likert scale questions.

The questionnaire was sent via e-mail to 108 logistics professionals from the automotive industry in 2008 , most of whom were suppliers of large vehicle assemblers, with industrial plants located in Brazil. Those professionals had all been trained in using the MMOG/LE assessment tool at least a year prior to their participation in the survey. The reason for not having sent the questionnaire to logistics people that had been trained more recently was that they would not have had enough time to get acquainted with the recommendation in great detail and would not yet have had enough time to fully implement it. That would make their participation in the survey less productive.

Unfortunately, ca. 25 of the invitation messages bounced back, due to wrong e-mail addresses which prevented them to reach the addressee. This reduced the number of potential respondents to about seventy. We received five filled-in questionnaires within three days and twenty other after sending a second e-mail message (five days later), insisting on the importance of the individual contribution of those who had been trained on MMOG/LE. The return rate was approx. $35 \%$, which was considered satisfactory. The existence of a certain bond between the participants and the researchers, considering that they had been the instructors involved in the MMOG/LE training, may have helped to achieve a higher return rate than usual for electronic surveys. Cohen (2003), Graeml and Csillag (2006), among others, worked with much lower return rates for their electronic surveys with respondents belonging to the manufacturing industry.

The survey intended to help the researchers to understand the level of contribution of MMOG/LE to the improvement of logistics processes, according to the respondents' perception. In order to accomplish that, the questions addressed critical issues related to the logistics operation, i.e., those that, if not suitably addressed, increase the risk of production collapse at the customer's shop floor, increasing costs in the short run. The questionnaire included, therefore, processes that were considered critical in the MMOG/LE recommendation, which are referred to as F3 processes3 (ODETTE and AIAG, 2006).

Table 1, below, presents the questions in the survey, for which the respondents needed to choose among one of the possible answers: "strongly agree", "agree", "I do not have an opinion", "disagree", "strongly disagree" or "our company was already very efficient with respect to this issue, even prior to MMOG/LE". Note that the titles in bold and underlined that appear in Table 1 were not included in the questionnaire, which only showed the statements with which the respondents had to agree or disagree.

We assigned value " 1 " to "strongly agree", "2" to "agree", "3" to "I do not have an opinion", "4" to "disagree", and " 5 " to "strongly disagree". The only alternative that was not converted into a numeric figure was "our company was already very efficient with respect to this issue, even prior to MMOG/LE". In this case, we were only interested in the number of times respondents chose this alternative. 


\section{Table 1 - Content of the survey}

\section{Strategy and improvement}

1. The MMOG/LE recommendation contributed to create indicators to measure the delivery performance to customers.

2. The MMOG/LE recommendation contributed to create indicators to measure supplier delivery performance.

3. The MMOG/LE recommendation contributed to create indicators to measure the ability to build to schedule (productivity: plan vs. actual).

\section{Work organization}

4. The MMOG/LE recommendation contributed to create contingency plans for emergency situations in the supply chain.

\section{Capacity and production planning}

5. The MMOG/LE recommendation contributed to increase the logistics personnel participation in the development of new products within the organization.

6. The MMOG/LE recommendation contributed to improve the comparison of available resources with customer requirements for the short and the long run.

7. The MMOG/LE recommendation contributed to assure that a process is in place to notify customers of any significant resource limitations in meeting the requirements.

8. The MMOG/LE recommendation contributed to automatically integrate the customer's programming information into the organization's planning system, avoiding manual data transfer.

\section{Customer interface}

9. The MMOG/LE recommendation contributed to assure that delivery forecasts are communicated electronically to the customer, avoiding manual data transfer.

10. The MMOG/LE recommendation contributed to assure that call offs are electronically communicated to the customer in order to reduce the impact to its operation.

11. The MMOG/LE recommendation contributed to assure that there is a process and support documentation to define standard packaging and back-up packaging, before start of production.

12. The MMOG/LE recommendation contributed to assure consistency between container content, labels and documentation.

13. The MMOG/LE recommendation contributed to create a process that ensures that the data content of all ASN's is complete and accurate in accordance with customer requirements and that it is transmitted at the time of conveyance departure.

\section{Production and product control}

14. The MMOG/LE recommendation contributed to create a process to correctly identify all material in stock.

15. The MMOG/LE recommendation contributed to create a process to clearly identify all storage locations accurately.

16. The MMOG/LE recommendation contributed to create a process to assure the appropriate identification of all unusable or damaged material.

17. The MMOG/LE recommendation contributed to create a formal engineering change/sign-off review process.

\section{Supplier interface}

18. The MMOG/LE recommendation contributed to create procedures that ensure that deviations from the materials planning and logistics instructions are immediately investigated, communicated and rectified by the supplier.

19. The MMOG/LE recommendation contributed to assure that the organization's suppliers are capable of sending and receiving electronic communication.

20. The MMOG/LE recommendation contributed to assure that electronic communication is implemented from/to all suppliers, sub-contractors and logistics providers. 


\section{RESULTS}

The data that were collected for this study represented a much richer information source than originally expected when we started the research. Due to space limitation, we will only present the results that we considered the most relevant ones.

From the 25 respondents, four acknowledged not having implemented MMOG/LE in their organizations, yet, although having the intention of doing it soon. Among the other 21 companies, implantation occurred 16 months before, on average. However, one of the respondents said that theyhis/her organization had only started implementing MMOG/ LE two months prior to the survey, which lead to the exclusion of that company from the analyzed sample, resulting in the responses of 20 companies being assessed.

We will first discuss the averages of the answers for each of the twenty questions. As explained before, the ordinal Likert scale was converted into a numerical interval scale, so that average calculations could be performed. On a second stage, we will also discuss the frequency of appearance of: "our company was already very efficient with respect to this issue, even prior to MMOG/LE". When this answer appeared it was recorded separately from the others, because it is not part of the ordinal scale. We hope that, by doing so, we provide readers with organized information that improves the understanding of the participants' perception about the effectiveness of MMOG/ LE as a logistics processes evaluation tool.

Analysis of the average and standard deviation of the answers

The five ordinal possibilities of answer ("strongly agree", "agree", "I do not have an opinion", "disagree", and "strongly disagree") were converted into numbers, with " 1 " being assigned to "strongly agree" and " 5 " to "strongly disagree". Then averages and standard deviations were calculated and presented in Table 2, below.

Table 2 - Averages and standard deviations for the twenty questions in the survey

\begin{tabular}{|l|c|c|c|c|c|c|c|c|c|c|}
\hline Question & $\mathbf{1}$ & $\mathbf{2}$ & $\mathbf{3}$ & $\mathbf{4}$ & $\mathbf{5}$ & $\mathbf{6}$ & $\mathbf{7}$ & $\mathbf{8}$ & $\mathbf{9}$ & $\mathbf{1 0}$ \\
\hline Median & 2.0 & 2.0 & 2.0 & 2.0 & 2.0 & 2.0 & 2.0 & 2.0 & 2.0 & 2.0 \\
\hline Average & 1.9 & 1.8 & 1.9 & 1.7 & 1.9 & 1.9 & 1.9 & 1.9 & 2.1 & 1.9 \\
\hline s.d. & 0.5 & 0.4 & 0.6 & 0.5 & 0.8 & 0.5 & 0.7 & 0.6 & 0.7 & 0.3 \\
\hline Question & $\mathbf{1 1}$ & $\mathbf{1 2}$ & $\mathbf{1 3}$ & $\mathbf{1 4}$ & $\mathbf{1 5}$ & $\mathbf{1 6}$ & $\mathbf{1 7}$ & $\mathbf{1 8}$ & $\mathbf{1 9}$ & $\mathbf{2 0}$ \\
\hline Median & 2.0 & 2.0 & 2.0 & 2.0 & 2.0 & 2.0 & 2.0 & 2.0 & 2.0 & 2.0 \\
\hline Average & 1.9 & 2.0 & 1.8 & 1.8 & 2.0 & 2.0 & 2.1 & 2.0 & 1.9 & 1.9 \\
\hline s.d. & 0.7 & 0.9 & 0.7 & 0.6 & 0.5 & 1.0 & 1.1 & 0.5 & 0.7 & 0.7 \\
\hline
\end{tabular}

Note: s.d. = standard deviation

The analysis of averages and standard deviations shows that the majority of the respondents "agrees" with most of the statements contained in the survey. Most averages were around 2 (median was 2 for all questions) and standard deviations were low. Only three participants marked "disagree" for at least one question. None marked "strongly disagree" for any question. This shows that the participants consider that the MMOG/LE helps them to improve their logistics performance. This emphasizes the increasing importance of systems and tools for performance measurement, which is consistent with the literature review.

It is important to stress that respondents were logistics professionals from the automotive industry, whose superior logistics performance has been demanded for many years by their powerful customers, usually large car assemblers.

\section{ANALYSIS OF THE FREQUENCY OF "OUR COMPANY WAS ALREADY VERY EFFI- CIENT WITH RESPECT TO THIS ISSUE, EVEN PRIOR TO MMOG/LE"}

The alternative "our company was already very efficient with respect to this issue, even prior to MMOG/ LE" was included in the survey after it was almost ready to be launched. As originally designed, the 
questionnaire contained only the traditional Likert scale options. However, during the preparation for the mail-merge launch, we decided to include this option because we thought it could provide some additional information at no extra cost, mainly in the case of companies that already had very strict controls on their logistics processes even before being introduced to MMOG/LE. This was a very fruitful decision, because it allowed us to work on a different direction, checking exactly where MMOG/LE was making a difference. Table 3 shows the number of times respondents claimed that their companies already mastered the specific logistics processes addressed by each question, even before implementing MMOG/LE.

\section{Table 3 - Frequency of answer "our company was already very efficient with respect to this issue, even prior to MMOG/LE"}

\begin{tabular}{|l|c|c|c|c|c|c|c|c|c|c|}
\hline Question & $\mathbf{1}$ & $\mathbf{2}$ & $\mathbf{3}$ & $\mathbf{4}$ & $\mathbf{5}$ & $\mathbf{6}$ & $\mathbf{7}$ & $\mathbf{8}$ & $\mathbf{9}$ & $\mathbf{1 0}$ \\
\hline Incidence & 6 & 6 & 5 & 2 & 6 & 2 & 4 & 5 & 5 & 3 \\
\hline$\%$ & $28.6 \%$ & $28.6 \%$ & $23.8 \%$ & $9.5 \%$ & $28.6 \%$ & $9.5 \%$ & $19.0 \%$ & $23.8 \%$ & $23.8 \%$ & $14.3 \%$ \\
\hline Question & $\mathbf{1 1}$ & $\mathbf{1 2}$ & $\mathbf{1 3}$ & $\mathbf{1 4}$ & $\mathbf{1 5}$ & $\mathbf{1 6}$ & $\mathbf{1 7}$ & $\mathbf{1 8}$ & $\mathbf{1 9}$ & $\mathbf{2 0}$ \\
\hline Incidence & 4 & 3 & 7 & 6 & 5 & 8 & 8 & 2 & 0 & 0 \\
\hline$\%$ & $19.0 \%$ & $14.3 \%$ & $33.3 \%$ & $28.6 \%$ & $23.8 \%$ & $38.1 \%$ & $38.1 \%$ & $9.5 \%$ & $0.0 \%$ & $0.0 \%$ \\
\hline
\end{tabular}

Note: these percentages were calculated based on the answers provided by 20 companies that filled in all questions in the survey.

The results were analyzed under two different perspectives: first of all, the high incidence of this answer was remarked for questions 16 and 17 . The fact that eight respondents (ca. 38\%) stated that their companies were already efficient in evaluating the performance of such logistics activities called the attention. Then, it was also noticed that no respondent chose the alternative "we already were very efficient at it prior to implementing MMOG/LE" for questions 19 and 20.

Based on such results, it is possible to infer that MMOG/LE was less effective to solve issues related to questions 16 and 17. On the other hand, it is also possible to infer that the tool is very important in dealing with the issues presented in questions 19 and 20.

Question 16 was "The MMOG/LE recommendation contributed to create a process to assure the appropriate identification of all unusable or damaged material". When trying to understand why so many respondents considered that they did not need the MMOG/LE for that (were already efficient before it), we thought that it may be related to the fact that all participants belonged to companies that were certified by QS 9000, ISO 9001:2000 or ISO/TS 16949, among other quality regulations4. Item 8.3 of ISO 9001:2000, for example, which is called "control of non-conforming product", demands any non-conforming product to be identified by means of a label or another suitable identification method, and segregated to avoid unintentional use. In addition to that, this norm determines that the identification of nonconforming items should take place at the time such materials are received, during the production process (work-in-process), before delivery to the customer (finished goods) and after delivery (MELLO et al, 2002). Thus, the high rate of participants saying that they were already efficient with respect to that prior to start using MMOG/LE is justified. MMOG/LE did not contribute to improvements with respect to that, in the opinion of several respondents. But this does not mean that MMOG/LE should not concern about the issue because there may be companies out there that do not have a formal quality system in place and could use MMOG/LE as an improvement tool5.

Question 17 states that "the MMOG/LE recommendation contributed to create a formal engineering change/sign-off review process". The relatively low impact of MMOG/LE for this probably also results from the fact that most quality norms deal with the issue. Item 7.3.7 of ISO 9001:2000, referred to as "Control of design and development changes", requires any change in design to be identified, critically analyzed, verified, validated and approved prior to its implementation. The norm also requires that the critical analysis of the design and development evaluates the effect of changes in component parts and in the product or service being delivered. This 
justifies the high percentage of respondents that said that they were already very efficient in that before MMOG/LE.

Question 19 contains the following statement: "the MMOG/LE recommendation contributed to assure that the organization's suppliers are capable of sending and receiving electronic communication" and question 20: "MMOG/LE recommendation contributed to assure that electronic communication is implemented from/to all suppliers, sub-contractors and logistics providers". As it can be seen, both questions deal with the capacity of sending and receiving electronic communication, involving the organization and its customers and suppliers. None of the participants acknowledged doing a good job with respect to this issue prior to their experience with the MMOG/LE recommendation. This demonstrates that, for these issues, MMOG/LE provided an important push towards the logistic performance qualification of those who implement it. The explanation of this result may be related to the fact that such demand is exclusively related to logistics concerns and, therefore, is not in the scope of other norms and recommendations, such as ISO 9001:2000 and other norms with overall quality concern. Another important reason for the fragility of the organizations' integration capabilities to their supply chains is that many of them still find it difficult to integrate their own internal functions. Coordinating activities with external partners is still a distant target.

In the MMOG/LE training sessions in Brazil, all of which were directly conducted by the researchers or, at least, managed by them, the electronic integration issue, involving suppliers and customers, has been one of the most concerning topics. It seems to be the "Achilles heel" of the logistics systems implemented by most automotive industry companies. In spite of the automotive industry being a technologically advanced sector, which is responsible for an important share of the GNP of a country like Brazil, the automation of information exchange is still a problem, particularly when the matter is connecting tier one suppliers to their suppliers and so forth. As one moves upstream the supply chain, either the size of the suppliers decreases, meaning they have less resources for technological investments, or the importance of the automotive industry decreases, to large suppliers of raw-materials, which reduces the automotive industry's bargaining power. Lack of resources or interest makes the task of convincing suppliers to heavily invest in technological resources to provide the infrastructure for reliable electronic communications a difficult one.

When the issue is the integration with customers, differently to what happens with respect to the integration with suppliers, a few participants already say that they were good at it even before the MMOG/ LE. We believe that, as all participants in the survey are tier one suppliers of a truck manufacturer, this major customer has used its bargaining power to ensure that its suppliers were suitably integrated to it. However, participants do not have the same bargaining power to force their own suppliers to do the same.

Analyzing the perception of the respondents about their competence with respect to logistics activities, the emphasis was on those cases where MMOG/LE has proven to be an important tool to improve the logistics performance and on those where it is not so relevant, because other norms and regulations have already addressed the issues, accordingly. The analysis could have been extended to the other questions in the survey, as they all represent F3 items, i.e., they are essential to prevent that interruptions happen on the delivery to the customer. Loss in the short run may result from poor performance. This was not done because of space limitations and also in order to focus the attention on the items that were discussed above. The reader is invited to reflect about the other issues. Data are available and were presented in Figures 2 and 3. It is important to highlight, though, that the small size of the sample may prevent statistically acceptable conclusions to be drawn.

\section{CONCLUSIONS}

This paper showed that, in spite of the fact that logistics became much more important than in the past, for most organizations and in different fields, there are still not many tools available and widely spread to measure its effectiveness. Based on that, it was justifiable to carry out research on the perceptions of logistics professionals about an evaluation tool that is quickly gaining adopters in the automotive industry, which was jointly developed by the two associations that congregate companies in the automotive sector in North America and Europe.

Most respondents agree that MMOG/LE is a useful tool to measure the performance of logistics processes and even those who have not implemented it yet say that they will do it soon. 
The study's major finding was that MMOG/LE is more useful to help companies to improve their performance concerning issues that were not directly addressed by previous quality norms and recommendations. Its importance became particularly clear in making its users understand that they need to integrate their processes electronically with those of their business partners, in order to improve the logistics flow (questions 18 to 20).

Maybe one could expect that companies that find it difficult to electronically integrate to their suppliers would also have problems to coordinate activities with their customers (questions 9 to 13). But this was not the case, as became clear after analyzing the frequency of the answer "our company was already very efficient with respect to this issue, even prior to MMOG/LE" for questions about the integration with suppliers and customers. In fact, it is not very difficult to understand why the frequency was much higher for the integration with customers, in the case of this survey: almost all respondents work as tier 1 suppliers, i.e. direct suppliers, of automotive assemblers. The integration to the customers is settled, because the customer is very important to their businesses. On the other hand, first tier suppliers are not always that important to their suppliers and do not have the same bargaining power to make their suppliers invest resources in sophisticated information technology to allow integration.

The issues for which MMOG/LE was considered less important are those that replicate demands of quality norms, mainly those concerning product and production control (questions 14 to 17).

In spite of the interesting results that were obtained, this study has a few limitations, which reduce the reach of its conclusions. The survey involved a limited number of respondents. Of course, the population of logistics professionals trained on MMOG/LE in Brazil is still small and even fewer are those who went through the experience of implementing the recommendation in their organizations, which represented the group whose comments and perceptions mattered for the study. The small sample increases the risks involved in any inference, as some results may result from chance. Another limitation of the research is that, as the respondents were introduced to the MMOG/LE recommendation by the researchers, themselves, in training sessions for the implantation in their organizations, some participants may have felt inclined to answer the questions not based on their own perceptions but on what they thought would impress the researchers.
The next step of this research project will be interviewing the customer of the participants in the current survey, i.e., the assemblers that give incentive to their suppliers to adopt MMOG/LE as an assessment tool for their logistics processes, in order to find if they believe that MMOG/LE helps their suppliers to improve their logistics performance. We also want to know if they have any hard evidence of improvement and of the correlation of such improvement to the use of the assessment tool.

Regardless of the logistics evaluation tool that is used by an organization to assess the quality of its logistics service, it is important that one such tool is indeed used, to allow improvements to be internalized, as it already happens with processes in other areas of the company. In that sense, we consider that the discussion that was carried out in this paper about MMOG/ LE is important not only for the results that were accomplished but also for having stimulated the debate about the need to assess logistics processes in order to improve their management.

\section{REFERENCES}

AIAG. (2006) AIAG and Odette announce release of updated Global Materials Management Operations Guideline/Logistics Evaluation (MMOG/LE). July 24, 2006. Available at: http://www.aiag.org/staticcontent/press/releases/GENERAL/PR_MMOGLE06_final.pdf. Access: 24/Feb/2008.

ABRAHAMSSON, Mats; ALDIN, Niklas; STAHRE, Redrik. (2003) Logistics platforms for improved strategic flexibility. International Journal of Logistics: Research and Applications. v. 6, no. 3, 2003.

ALDER, Ken. (2007) A passion for precision. American Scientist. v. 95, n. 3, p. 273-274. May/Jun, 2007.

ALVES FILHO, Alceu Gomes; RACHID, Alessandra; DONADONE, Júlio Cesar; MARTINS, Manoel Fernando; TRUZZI, Oswaldo Mário Serra; BENTO, Paulo Eduardo Gomes; VANALLE, Rosângela Maria. (2002) Manufacturing strategies and work organization in an engine supply chain. RAEelectrônica. v. 1, n. 1, 2002.

BURKHALTER, Bettye B. (1994) The evolution of a continuous quality improvement process in a university setting: a working model for consideration. Total Quality Management. v. 5, n. 4, p. 169-184. Jul., 1994.

COHEN, Max. (2003) Uso da informação na economia de informação: um estudo na indústria do estado de São Paulo [Use of information in the information economy: a study with manufacturers in Sao Paulo state]. 2003. 133 p. Doctoral Thesis - Escola de Administração de Empresas de São Paulo, São Paulo, 2003.

COSTA, Jaciane Cristina; MAÇADA, Antônio Carlos Gastaud. (2009) Gestão da informação interorganizacional na cadeia de suprimentos automotiva [Interorganizational information 
management in the automotive supply chain]. RAE-eletrônica, v. 8, n. 2, 2009.

ERICSSON, K. Anders; PRIETULA, Michael J.; COKELY, Edward T. (2007) The making of an expert. Harvard Business Review, v. 85, n. 7/8, p. 114-121. Jul/Aug, 2007.

FERREIRA, Karine Araújo; ALVES, Maria Rita Pontes Assumpção. (2005) Logística e troca eletrônica de informação em empresas automobilísticas e alimentícias [Logistics and electronic information interchange in automotive and food companies]. Produção. v. 15, n. 3, p. 434-447. 2005.

GEBLER, David. (2006) Is Your Culture a Risk Factor? Business \& Society Review. v. 111, n. 3, p. 337-362. Fall, 2006.

GRAEML, Alexandre Reis; CSILLAG, João Mário. (2006) Application of an e-mail survey using a Word form. In: Annual Conference of POMS. 17., 2006, Boston, MA. Proceedings... Boston: Poms, April 28 - May 1, 2006.

HARO, Daniel Garcia; CERONI-DA-SILVA, Sílvio; CATEN, Carla S. (2001) Sistemas da qualidade na indústria automobilística: uma proposta de auto-avaliação unificada [Quality system in the automotive industry: a proposal for standardized self-assessment]. In: Encontro Nacional de Engenharia de Produção (Enegep) [Production Engineering National Meeting]. 21., 2001, Salvador. Proceedings... Salvador: ABEPRO, 2001.

HARRINGTON, Lisa. (2005) Supplier logistics in the driver's seat. Inbound Logistics. July, 2005. Available at: http://www. inboundlogistics.com/articles/features/0705_feature04.shtml. Access: 24/02/2008.

HIJJAR, Maria Fernanda; GERVÁSIO, Maria Helena; FIGUEIREDO, Kleber Fossatti. (2005) Mensuração de desempenho logístico e o modelo world class logistics [Logistics performance measurement and the world class logistics model]. 2005. Available at: http://www.centrodelogistica.org/new/ fs-busca.htm?fr-public.htm. Access: 21/Feb/2008.

HIRSCHMAN, A. O. (1958) The strategy of economic development. New Haven, CT: Yale University Press, 1958.

INTERNETAUTOGUIDE. (2004) AIAG Announces Global Materials Management Guidelines. InternetAutoguide.com. April 6, 2004. Available at: http://www.internetautoguide.com/ auto-news/25-int/639/index.html. Access: 24/Feb/2008.

LA VALLE, Cesar. (2007) Pesquisa benchmarking 2007: Serviço de distribuição física. [Benchmark research 2007: physical distribution services]. 2007. Available at: http://www.centrodelogistica.org/new/artigos_coppead/Coppead_142_completo. pdf. Access: 21/Feb/2008.

MARTINS, Denise Maria; GONÇALVES, Marilson Alves. (2004) Eficácia dos indicadores de desempenho na cadeia de fornecimento automotivo [Effectiveness of performance indicators for the automotive supply chain]. In: Simpósio de Administração da Produção, Logística e Operações Industriais. 7., 2004, São Paulo. Proceedings... São Paulo: FGV-EAESP, Oct. 2004.

MELLO, Carlos H. Pereira; SILVA, Carlos Eduardo; TURRIONI, João; SOUZA, Luiz. (2002) ISO 9001:2000: Sistema de gestão da qualidade para operações de produção e serviços [ISO 9001:2000: Quality management system for product/service operations]. São Paulo: Atlas, 2002.

NELSON, Bob. (2007) Strategic Recognition. Leadership Excellence. v. 24, n. 2. Feb., 2007.

NEUMANN, Norbert; RIEDEL, Ralph; MÜLLER, Egon. (2007) The impact of outsourcing on an organizations ability to innovate. In: Annual International Conference of the European Operations Management Association (EurOMA). 14., 2007, Ankara. Proceedings... Ankara: Euroma, 17-20 June, 2007.

NUGENT, Patrick. (2007) Add value with measurement. Quality. v. 46, n. 9, p. 30-32, Sep., 2007.

ODETTE; AIAG. (2006) Global Materials Management Operating Guideline/Logistics Evaluation. Odette's Global document downloads. 2006. Available at: http://www.odette.org/ html/ gldownloads.htm. Access: 01/Mar/2008.

RODRIGUES, Diego Mondadori; SELLITTO, Miguel Afonso. (2008) Práticas logísticas colaborativas: o caso de uma cadeia de suprimentos da indústria automobilística [Collaborative logistics practices: the case of a supply chain in the automotive industry]. Revista de Administração, v. 43, n. 1, p. 97111, 2008.

SCAVARDA, Luís Felipe Roriz; HAMACHER, Sílvio. (2001) Evolução da cadeia de suprimentos da indústria automobilística no Brasil. Revista de Administração Contemporânea, v. 5, n. 2, p. 201-219, 2001.

SILVA, Andrea Lago da; ALCÂNTARA, Rosane Chicarelli. (2001) Mudanças nos relacionamentos e estratégias para melhor coordenação da cadeia de suprimentos [Changes in relationships and strategies for better coordination of supply chain]. Revista de Administração. v. 36, n. 3, p. 49-58, 2001.

TEIXEIRA, Rafael; LACERDA, Daniel Pacheco. (2010) Gestão da cadeia de suprimentos: análise dos artigos publicados em alguns periódicos acadêmicos entre os anos de 2004 e 2006. [Supply chain management: analysis of papers published on academic journals between 2004 and 2006]. Gestão e Produção. v. 17, n. 1, p. 207-227, 2010.

TONTINI, Gérson; ZANCHETT, Ricardo. (2010) Atributos de satisfação e lealdade em serviços logísticos [Satisfaction and loyalty attributes in logistics services]. Gestão e Produção, v. 17, n. 4, p. 801-816, 2010.

WANKE, Peter; FLEURY, Paulo Fernando; HIJJAR, Maria Fernanda. (2007) Um estudo do impacto da sofisticação logística dos embarcadores brasileiros industriais no padrão de contratação dos serviços de operadores logísticos [A study about the impacts of the increase in logistics sofistication of Brazilian industrial shippers when selecting third party logistics providers]. In: Encontro Nacional da Associação Nacional de Pós-Graduação e Pesquisa em Administração (Enanpad) [Meeting of the Research and Graduate Studies National Association]. 32., 2007, Rio de Janeiro. Proceedings... Rio de Janeiro: Anpad, Sep. 2007.

WITT, Clyde E. (2005) Guidelines developed by the auto industry offer a roadmap for enhanced material handling, ease the identification performance gaps in the supply chain, and establish long-needed performance benchmarks. Material Handling Management. v. 60, n. 5, p. 20-29, May 2005. 
YAN, Jianyuan; CHAUDHRY, Peggy E.; CHAUDHRY, Sohail S. (2003) A model of a decision support system based on casebased reasoning for third-party logistics evaluation. Expert Systems. v. 20, n. 4, p. 196-207. Sep., 2003.

\section{Notes}

1 This expression is many times assigned to Peter Drucker (NELSON, 2007; GEBLER, 2006), other times to the quality gurus (BURKHALTER, 1994). Some even consider that its origins are much remoter. Lord Kelvin, in the XIXth century would have used the statement (ERICSSON, PRIETULA, COKELY, 2007), alerting that "when you can measure what you are speaking about and express it in numbers, you know something about it; but when you cannot measure it, when you cannot express it in numbers, your knowledge of it is of a meager and unsatisfactory kind" (ALDER, 2007; NUGENT, 2007). Galileo could also have been the source of inspiration for such expression, when he recomended, still in the XIVth century, that one should "measure what is measurable, and make measurable what is not so" (NUGENT, 2007).

2 Ford in North America used the Q1 logistics certification system, Renault in France and Volvo in Sweden used EAQL. They all migrated or are migrating to MMOG-LE. The German assembler Volkswagen is still using the VBA system (Odette Logistic Evaluation) to evaluate the logistics of its suppliers. Peugeot and Citroën, in France, continue using EAQL, according explained to the authors by an automotive logistics specialist.

3 In addition to the critical processes (F3), MMOGLE also addresses other logistics processes that have lower impact on the supply chain, when they are poorly executed, but that still need to be controlled in order to increase the quality of the logistics flow. Such processes are called F2 (medium impact) and F1 (little impact).

4 Read Haro, Ceroni-da-Silva and Caten (2001) for a better idea of the huge number of quality norms and recommendations used by the automotive industry.

5 In the automotive sector, it is difficult to find any player, at least among the assemblers' tier 1 and tier 2 suppliers, that does not have a formally implemented quality system, as this has been a demand from automakers for many years.

\section{AUTHOR'S BIOGRAPHY}

Alexandre Reis Graeml holds a Doctor and a Master's degree in Business Administration (Operations Management and Information Systems Management) from Fundação Getúlio Vargas (FGV-EAESP), in Sao Paulo. He is currently an associate professor at the Graduate School of Business of Universidade Positivo and at the Information Systems Department of the Federal University of Technology - Parana (UTFPR). His research interests involve the Internet's impact on organizations and our society, IS issues in general, information flow along supply chains, social research networks and ethics in academia.

Jurandir Peinado is a doctoral student in business administration at Universidade Positivo. He holds a master's degree in Production Engineering from the Federal University of Santa Catarina. He is currently an assistant professor at the Engineering School at Universidade Positivo. His research interests are in the field of production engineering, with an emphasis on production, materials management and project management, mainly on the following themes: logistics, project management, lean production and production management. 